\title{
SPEAKING WITH DEBATE METHODS: CLASS ACTION RESEARCH STUDY
}

\author{
*Nana Fauzana Azima ${ }^{1}$, Taufina ${ }^{2}$ and Ahmad Zikri ${ }^{1}$ \\ ${ }^{1}$ Post GraduateElementary Education Universitas Negeri Padang \\ ${ }^{2}$ Lecturer Elementary EducationUniversitas Negeri Padang \\ E-mail:nanafauzana15@gmail.com
}

*Corresponding Author, Received: November 12, 2018, Revised: December 10, 2018, Accepted: December 21, 2018

\begin{abstract}
The purpose of this study is to describe the improvement in speaking skills of students using the debate method in class V of SDN 10 Sapiran Bukittinggi. The types of research are PTK, qualitative and quantitative approaches. The research subjects were teachers and 26 fifth grade students of SDN 10 Sapiran Bukittinggi. Planning cycle I obtained a percentage of $82.14 \%$, cycle II $92.85 \%$. The implementation of the first cycle was $81.25 \%$, the second cycle was $95 \%$. Speaking skills in cycle I $78.54 \%$, cycle II $93.15 \%$. Thus, the debate method can improve the speaking skills of fifth grade students of SDN 10 Sapiran Bukittinggi.
\end{abstract}

Keywords: Speaking Skills, Debate Methods, Elementary School

\section{INTRODUCTION}

Learning in elementary schools should invite students to interact between students and teachers. Current learning is centered on the teacher and students only follow what is taught by the teacher (Kus, 2015). One of the important aspects in learning Indonesian. Speaking skills must be well mastered by students, in order to communicate well in everyday life. Students can speak effectively with their speaking skills (Srikaew et al., 2015). One of the speaking skills can be applied using the debate method. The debate method applied in learning aims to make students dare to express and maintain their opinions and ideas correctly and logically (Lungu, 2015). Good speaking or communication skills are very important. If someone does not have good speaking skills, he will have difficulty in facing life (Khan and Ali, 2010). Speaking skills are indispensable for personal self, education, and career In the world of education 


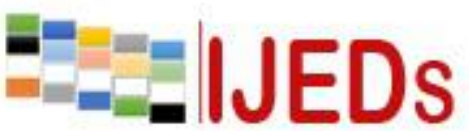

http://ijeds.ppj.unp.ac.id/index.php/IJEDS

\section{International Journal of Educational Dynamics}

Vol. 1 No. 1 (pp. 175-179) December 2018

p_ISSN 2655-4852

e_ISSN 2655-5093

and the world of work good speaking skills are needed to develop one's ideas, knowledge, and opinions (Herbein et al., 2018). To improve students' speaking skills, teachers can ask challenging questions and assignments, so that students can give more opportunities to talk (Afshar and Rahimi, 2014).

There are several skills that must be mastered by students, namely communication skills including listening, asking, writing, inviting, and displaying. Furthermore, interpersonal skills such as group work (Benghazi et al, 2010). Primary school children need to be given a public speaking training program to improve their ability to speak in public and reduce their insecurity when speaking (Herbein et al, 2018). Public speaking is a skill students must master in elementary school. However, this is still rarely found in elementary schools. For this reason, it is necessary to develop public speaking skills training in elementary schools (Herbein et al., 2018).

\section{METHOD}

This study uses a type of classroom action research using qualitative and quantitative data analysis with research subjects in fifth grade students of Sapiran Bukittinggi 10 Elementary School in the second semester of the 2016/2017 Academic Year with 26 students. (Primary Data of 10 Sapiran Public Elementary School Bukittinggi, 2018). This study uses the flow of the research model Kemmis in Arikunto, 2009). Broadly speaking there are four stages that are passed, namely (1) planning, (2) implementation, (3) observation, and (4) reflection.

\section{RESULTS AND DISCUSSION}

\section{First Cycle and First Meeting}

The results obtained are based on observations of the RPP in the first cycle of meeting 1, namely with a score of 22 from a maximum score of 28 , a percentage of $78.57 \%$ in the category of Enough (C). Based on the results of observations made on the teacher's actions, in the first cycle of meeting I learning the number of scores obtained was 30 from a maximum score of 40 with a percentage of $75.00 \%$ in the Enough category. While students, scores obtained 30 from a maximum score of 40 with a 


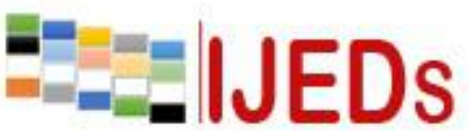

http://ijeds.ppj.unp.ac.id/index.php/IJEDS

percentage of $75.00 \%$ with sufficient categories. Based on the assessment of speaking skills, it was obtained an illustration that of the 26 students only 14 students were able to reach the standard of mastery learning and 12 students had not been able to reach the standard of mastery learning The percentage of the class average is $74.76 \%$. The value of the speaking skills obtained can be explained: (1) Non-linguistic aspects, the average percentage is $75.00 \%$ with sufficient categories (C); (2) Language aspects, average percentage of $74.50 \%$ with sufficient category (C).

\section{First Cycle and Second Meeting}

The results of observations of the RPP, learning the first cycle of meeting II obtained a score of 24 from a maximum score of 28 , the percentage of $85.72 \%$ with a good category (B). Based on the results of observations of the teachers actions, the total score obtained was 35 from a maximum score of 40 with a percentage of $87.50 \%$ with a good category (B). Whereas for student actions, the score obtained is 35 from a maximum score of 40 with a percentage of $87.50 \%$ in good category (B). Students speaking skills are seen from the results of observations. Obtained an overview of 26 students, only 19 students were able to reach the standard of mastery learning and 7 students had not yet reached the minimum completeness standard. The percentage of class average obtained is $82.34 \%$. The value of the speaking skills obtained can be described: (1) Non-linguistic aspects, with an average percentage of $81.51 \%$ with good categories (B); (2) Language aspects, with an average percentage of $83.17 \%$ with good categories (B).

\section{Second Cycle}

The results of observations on the RPP, learning cycle II the number of scores obtained 26 from a maximum score of 28 , the percentage of $92.85 \%$ with a very good category (A). Based on the results of observations made on the teacher's actions, the scores obtained were 38 from a maximum score of 40 with a percentage of $95.00 \%$ with a very good category (A). As for the actions of students, the scores obtained were 38 from a maximum score of 40 with a percentage of $95.00 \%$ with a very good category (A). The learning cycle II of the score was obtained from the maximum score of 28 , the percentage of $92.85 \%$ with a very good category (A). Based on the results of observations made on the teacher's actions, the scores obtained were 38 from a 


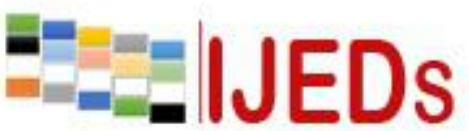

http://ijeds.ppj.unp.ac.id/index.php/IJEDS

\section{International Journal of Educational Dynamics}

Vol. 1 No. 1 (pp. 175-179) December 2018

p_ISSN 2655-4852

e ISSN 2655-5093

maximum score of 40 with a percentage of $95.00 \%$ with a very good category (A). As for the actions of students, the scores obtained were 38 from a maximum score of 40 with a percentage of $95.00 \%$ with a very good category (A).

\section{CONCLUSION}

The lesson plan is designed with the stages of the debate method with step 1) The teacher gives a brief explanation of the day's activities, 2) the teacher forms a small group (2-4 students) and shares the case according to his role, 3 ) the group sits face to face with other groups, while the group of leaders is in the middle rather to the side, 4) the concluding group invites the debate group to start, 5) after finishing the debate, the group of conclusors presents the results in front of the class, 6) the other groups give responses, 7) the student who presents can defend his opinion, group friends may help, 8) the teacher reflects on the results of the day's learning. The first cycle RPP obtained $82.14 \%$ then increased in the second cycle to $92.85 \%$ with very good qualifications.

\section{REFERENCES}

Abbas, S. 2006. Pembelajaran Bahasa Indonesia yang Efektif di SekolahDasar. Jakarta: Depdiknas

Arief, D. 2014. Peningkatan Keterampilan Berbicara Siswa Sekolah Dasar Menggunakan Media Gambar. Jurnal Ilmiah Ilmu Pendidikan 14. (II). 1-5

Arikunto, S. 2009. Penelitian Tindakan Kelas. Jakarta: Bumi Aksara

Afshar, H. S., and Rahimi, M. 2014. The Relationship among Critical Thinking, Emotional Intelligence, and Speaking Abilities of Iranian EFL Learners. Procedia - Social and Behavioral Sciences, 136, 75-79. https://doi.org/10.1016/j.sbspro.2014.05.291

Benghazi, K., Hurtado, M. V., Bermúdez-Edo, M., and Noguera, M. 2010. Enabling customizable virtual debate environments in higher education. Procedia - Social and Behavioral Sciences, 2(2), 3319-3323. https://doi.org/10.1016/ j.sbspro.2010.03.508

Haryadi and Zamzami. 1996. Peningkatan Keterampilan Berbahasa Indonesia.Yogyakarta: Depdikbud

Herring, J. 2011. Cara Tepat Berdebat.Jakarta: Buana Ilmu Populer

Herbein, E., Golle, J., Tibus, M., Schiefer, J., Trautwein, U., and Zettler, I. 2018. Fostering Elementary School Childrens Public Speaking Skills: A Randomized Controlled Trial. Learning and Instruction, 55(October 2017), 158-168. https://doi.org/10.1016/j.learninstruc. 2017.10.008 
http://ijeds.ppj.unp.ac.id/index.php/IJEDS

Herbein, E., Golle, J., Tibus, M., Zettler, I., and Trautwein, U. 2018. Putting a Speech Training Program into Practice: Its Implementation and Effects on Elementary School Childrens Public Speaking Skills and Levels of Speech Anxiety. Contemporary Educational Psychology, 55(September), 176-188. https://doi.org/10.1016/j.cedpsych.2018.09.003

Khan, N., and Ali, A. 2010. Improving the Speaking Ability in English: The students Perspective. Procedia - Social and Behavioral Sciences, 2(2), 3575-3579. https://doi.org/10.1016/j.sbspro.2010.03.554

Kus, Z. 2015. Participation Status of Primary School Students. Procedia - Social and Behavioral Sciences, 177(July 2014), 190-196. https://doi.org/10.1016/ j.sbspro.2015.02.381

Lungu, I. 2015. A New Model of Professionalization of Teachers in Pre-school and Primary School Education. Procedia - Social and Behavioral Sciences, 180(November 2014), 632-638. https://doi.org/10.1016/j.sbspro.2015.02.171

Srikaew, D., Tangdhanakanond, K., and Kanjanawasee, S. 2015. Development of an English Speaking Skill Assessment Model for Grade 6 Students by Using Portfolio. Procedia - Social and Behavioral Sciences, 191, 764-768. https://doi.org/10.1016/j.sbspro.2015.04.715 